\title{
IDEAŁ WYCHOWANIA FASZYSTOWSKIEGO
}

\author{
Dominik Figiel, dfigiel.uwr@gmail.com \\ Uniwersytet Wrocławski \\ pl. Uniwersytecki 1, 50-137 Wrocław
}

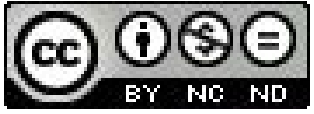

\section{STRESZCZENIE}

Faszyzm szczególnie w pierwszej połowie XX w. obecny był w poglądach wielu przedstawicieli totalitaryzmów Europejskich i nie tylko. Miał swoich zwolenników, m.in. w: Hiszpanii za czasów sprawowania władzy przez Francisco Franco, Portugali za rządów António de Oliveira Salazara , rumuńskiej Żelaznej Gwardii Corneliu Zelea Codreanu, Belgii wśród zwolenników faszystowskiego Christus Rex, Polsce, Wielkiej Brytanii , Francji oraz przede wszystkim we Włoszech Benito Mussoliniego. Idea faszyzmu towarzyszyła wielu dyktatorom i przedstawicielom ugrupowań politycznych na świecie, jednak jej fundamenty stworzył Benito Mussolini. Jak trafnie stwierdził Jerzy W. Borejsza Mussolini był pierwszy.

Zatem przedmiotem artykułu jest włoski faszystowski ideał wychowania. Są to wstępne refleksje nad obrazem jednostki kreowanym przez włoskich ideologów. Pozwala to prześledzić rozprzestrzenianie się idei faszyzmu do nauk o wychowaniu, a także pokazać różne aspekty tak zdefiniowanej doktryny. W artykule przedstawiono ogólną koncepcję i definicję ideału wychowania, która pozwoli uporządkować zdobytą wiedzę z perspektywy teoretyków włoskiego faszyzmu. Celem jest przedstawienie koncepcji Nowego Człowieka dotyczącej stworzenia, podporząakowania i wychowania idealnej jednostki.

Słowa kluczowe: faszyzm, wychowanie, ideał wychowania, Benito Mussolini, historia wychowania, Włochy, Nowy Człowiek

\section{Fascist ideal of upbringing}

Abstract

Fascism especially in first half of XX century was present in outlooks of many representatives of european totalitarianisms. He had his supporters in Spain at the time of exercised of power by Francisco Franko, Portugal during the reign of António de Oliveira Salazar, Romanian Iron Guard Corneliu Codreanu Zelea, Belgium among supporters of the fascist Christus Rex, Poland, Great Britian, France and primarily in Benitos Mussolini Italy. The idea of fascism was accompanied many dictators and representatives of political parties in the world, however, its foundations was created by Benito Mussolini. As aptly stated Jerzy W. Borejsza Mussolini was the first.

Therefore, the subject of the article is the Italian fascist ideal of upbringing. These are the preliminary reflections on the image of the individual created by Italian ideologues. This allows to trace the spread of the ideas of fascism to science education and and show different aspects so defined doctrine. The article presents a general concept and definition of the ideal of upbringing, which allows organize the acquired knowledge from the perspective of theorists of Italian fascism. The aim is to present the concept of the New Man concerning on the creation, to gain control of the individual and upbringing of ideal individual.

Key Words: fascism, upbringing, ideal of upbringing, Benito Mussolini, history of upbringing, Italy, New Men

\section{WPROWADZENIE}

Faszyzm szczególnie w pierwszej połowie XX w. obecny był w poglądach wielu przedstawicieli totalitaryzmów Europejskich i nie tylko. Miał swoich zwolenników, m.in. w: Hiszpanii za czasów sprawowania władzy przez Francisco Francoํ, Portugali za rządów António de Oliveira Salazara², rumuńskiej Żelaznej Gwardii Corneliu Zelea Codreanu,

1 S. G. Payne, Fascism in Spain, 1923-1977, Falange: A History of Spanish Fascism, Stanford 1967. N. Davies, Europa, Kraków 1998. M. Langholz, Fascism in Spain, Munich 2010. Falanga - organizacja faszystowska w Hiszpanii.

2 Nazwa Drugiej Republiki Portugali - Estado Novo. 
Belgii wśród zwolenników faszystowskiego Christus Rex, Polsce, Wielkiej Brytanii ${ }^{4}$, Francji ${ }^{5}$ oraz przede wszystkim we Włoszech Benito Mussoliniego. Idea faszyzmu towarzyszyła wielu dyktatorom i przedstawicielom ugrupowań politycznych na świecie, jednak jej fundamenty stworzył Benito Mussolini. Jak trafnie stwierdził Jerzy W. Borejsza ${ }^{6}$ Mussolini bylpierwszy.

W związku z tym przedmiotem artykułu jest włoski faszystowski ideał wychowania. Z perspektywy historii wychowania jest to temat, któremu nie poświęca się wiele uwagi. Toteż będą to wstępne refleksje nad obrazem jednostki kreowanym przez włoskich ideologów. Pozwala to prześledzić rozprzestrzenianie się idei faszyzmu do nauk o wychowaniu, a także pokazać różne aspekty tak zdefiniowanej doktryny. W artykule przedstawiono ogólną koncepcję i definicję ideału wychowania, która pozwoli uporządkować zdobytą wiedzę z perspektywy teoretyków włoskiego faszyzmu.

\section{IDEAE WYCHOWANIA}

Stefan Kunowski stwierdził, że wychowanie to „społecznie uznawany system działania pokoleń starszych na dorastające, celem pokierowania ich wszechstronnym rozwojem dla przygotowania według określonego ideału nowego człowieka do przyszłego życia"7 . W ruchu faszystowskim stawiano przede wszystkim na młodych, którzy w przyszłości mieli rządzić państwem i stać się jego obrońcami. Postulowano także stworzenie „nowego człowieka”, idealnego, lepszego. Wszystko odbywać się miało pod przewodnictwem starszych, doświadczonych kombatantów I wojny światowej.

W jaki jednak sposób należy rozumieć ideał wychowania i jakie cechy powinna posiadać jednostka w odniesieniu do definicji S. Kunowskiego? Ideał wychowania to „pełen zestaw harmonijnie zintegrowanych ze sobą celów, dający w sumie opis dojrzałej osobowości człowieka”. . Feliks Araszkiewicz stwierdza, że „ideał nie jest abstrakcyjną konstrukcją myślowa, lecz konkretnym systemem wartości, którego desygnaty są realnością i podlegają empirycznej weryfikacji”" Ideał ma określona strukturę, poszczególnymi jego elementami są zhierarchizowane cele wychowania. Realizacja danego celu zbliża bowiem kształt osobowości wychowanka do ideału.

W ten sposób na „podstawie analizy formalnej można opisać ideał i jego strukturę, zaś na podstawie analizy merytorycznej, treść konkretnych ideałów. Analiza formalna ideału wychowawczego wchodzi w zakres teleologii wychowawczej, zaś analiza merytoryczna w skład aksjologii wychowania. Teleologia wychowania określa zasady stanowienia i współzależności ideału i celów wychowania. Jedną z ważniejszych jest zasada spójności treści ideału i celów wychowania. Oznacza to, że poprzez realizację konkretnych celów, urzeczywistnia się treści ideału w osobowości wychowanka. Cele na każdym szczeblu wdrażania w praktyce muszą wynikać z przyjętego ideału. Z kolei aksjologia wychowania - określa wartość dyspozycji rozwijanych w procesie wychowania, oraz wskazuje, jaki zestaw wartości powinni zinternalizować wychowankowie. Zajmuje się zatem analizą źródeł wartości w wychowaniu oraz dokonuje ich klasyfikacji”10.

W teleologii wychowawczej istotne jest ukazywanie procesu kształtowania się ideałów wychowania oraz wyprowadzanych z nich celów i zadań w powiązaniu z czynnikami społeczno-politycznymi, ekonomicznymi oraz układem sił politycznych oraz z ideologią wychowawczą będącą zawsze pochodnąi ideologii społecznej określonych klas społecznych, a także z aktualnym $w$ danym czasie stanem nauk pedagogicznych ${ }^{11}$. Toteż „ideał wychowania jest problemem teoretycznym ${ }^{\prime \prime 2}$. Dzięki temu można było uzyskać spektrum wymagań, które stawiano dzieciom i młodzieży okresu totalitarnych Włoch. Doktryna faszyzmu zawierała całokształt anatomii ${ }^{13}$ ideału wychowania faszystowskiego określonego przez czołowych przedstawicieli m.in. B. Mussoliniego oraz Giovanniego Gentilego.

\section{FASZYZM}

3 Związek Faszystów Polskich, Polska Organizacja Faszystowska, Organizacja Faszystów Polskich.

4 Brytyjska Unia Faszystów założona przez Oswalda Mosleya.

5 Założyciel Georges Valois.

6 J. W. Borejsza, Mussolini byt pierwszy, Warszawa 1989.

7 S. Kunowski, Podstawy wspótczesnej pedagogiki, Warszawa 1981, s. 189.

8 M. Nowak, Teorie i koncepcje wychowania, Warszawa 2008, s. 346.

9 F. Araszkiewicz, Warunki prawomocności ideału wychowawczego, „Człowiek i Światopogląd” 1984, nr 9, s. 21.

10 L. Zarzecki, Teoretyczne podstawy wychowania. Teoria i praktyka w zarysie, Jelenia Góra 2012, s. 55-56.

11 F. Araszkiewicz, Idealy wychowawcze Drugiej Rzeczypospolitej, Warszawa 1978, s. 14.

12 L. Zarzecki, dz. cyt., s. 57.

13 Ideał wychowania jest fenomenem anatomicznym, szczególnie jeżeli chodzi o opis jednostki, jej postaw, wartości, światopoglądu, budowy fizycznej, cech osobowości, a także relacji międzyludzkich. Działanie wszystkich wymienionych mechanizmów (elementów ciała) określa jednostkę doskonałą, działającą według określonego przez ideologów faszyzmu planu, czy systemu. 
Ideologia faszystowska nie była tylko kreacją Mussoliniego, była „również wyrazem idei, mitów i programów ruchu masowego wyrosłego z doświadczeń Wielkiej Wojny i antysocjalistycznej reakcji klas średnich. Uzyskując własną autonomię, jako nowa, zorganizowana siła polityczna, pretendująca nie tylko do obrony ładu ekonomicznego, opartego na własności prywatnej, ale także zdecydowana przeprowadzić rewolucję polityczną i kulturalna, przez zburzenie ustroju liberalnego i stworzenie nowego państwa, zaprojektowanego według nieznanej dotychczas formy totalitarnej organizacji społeczeństwa obywatelskiego i systemu politycznego" ${ }^{\prime 14}$. Faszyzm według Gentile był „najpełniejszą realizacją państwa totalitarnego, zbudowanego na prymacie polityki i na rozpłynięciu się tego, co prywatne, w tym, co publiczne. Konsekwencją tej koncepcji było podporządkowanie życia indywidualnego i zbiorowego absolutnej supremacji Państwa, realizowanej za pomocą totalnej organizacji nieustannej mobilizacji ludności. Były to główne narzędzia polityki masowej, opartej na racjonalnym używaniu irracjonalności, działające za pośrednictwem mitologii i liturgii politycznej, a mające za zadanie kształtowanie sumienia indywidualnego i zbiorowego zgodnie z modelem nowego człowieka"15. Na tej podstawie „istotą faszyzmu włoskiego był swoisty kult państwa. W formule często przytaczanej przez Mussoliniego filozof idealizmu G. Gentile deklarował: wszystko dla państwa; nic przeciw państwu; nic poza państwem. Zobowiązania polityczne jednostki są więc absolutne i rozciagają się na wszelkie dziedziny" ${ }^{\prime \prime 16}$.

„Należy zaznaczyć, że w doktrynie faszyzmu odrzucano teorię na rzecz praktyki. Etos faszystowski był emocjonalny i sentymentalny: na tej płaszczyźnie cele działania były mniej ważne niż samo działanie, a siły, które prowadziły ludzi do obozu faszystowskiego, gotowe były poprzeć każdą stronę, pod warunkiem, że będą miały możność pofolgowania sobie - im gwałtowniej, tym lepiej. Różne postacie, które działały po kolei, w różnych partiach, dążyły raczej do czynów niż do idei, raczej do władzy niż do zasad"17. W konsekwencji dążono do stworzenia faszystowskiej klasy kierowniczej, arystokracji „nowego państwa", klasy o własnym charakterze i celach oraz z własnym mitem historycznym do urzeczywistnienia. W celu rozwiązania tego problemu skorzystano z trzech głównych składowych faszyzmu, czyli gentiliańskigo idealizmu, nacjonalizmu i syndykalizmu. Idealizm zdołał uzyskać przewagę ideologiczną i kulturalna, a nacjonalizm narzucić rodzącemu się ustrojowi strukturę państwa autorytarnego. Jedynym przegranym był syndykalizm, któremu nie udało się ze związków zawodowych uczynić fundamentalnej instytucji „nowego państwa”18. Tendencje totalitarne faszyzmu uwidaczniały się m.in. ze względu na skrajny kolektywizm, który leżał w sercu ideologii faszystowskiej; cel, jakim było stworzenie „faszystowskiego człowieka” - lojalnego, oddanego i zupełnie posłusznego - skutecznie wymazuje różnice między egzystencją publiczną a prywatną. Dobro kolektywnego ciała, narodu czy rasy stało zdecydowanie ponad dobrem jednostki, egoizm kolektywny pochłonął egoizm indywidualny ${ }^{19}$.

Cel stworzenia "nowego człowieka”, który pojawiał się w publikacjach włoskich ideologów, bardzo szczegółowo został opisany m.in. przez G. Gentile.

\section{Gentile I MusSOLINI - KONCEPCJA NOWEgo CZŁOWIEKA}

Nowym typem Włocha, wyobrażonym przez Gentiliego, był Mussolini: „temperament Mussoliniego odpowiada temperamentowi Mazziniego". W faszystowskiej koncepcji Gentiliego Mussolini grał rolę o wielkim znaczeniu: duce był według niego człowiekiem- osobowością kosmiczno-historyczna, w której urzeczywistniał się świat ducha. W Mussolinim wyrażała się treść faszyzmu. Idea ta stawała się rzeczywistością poprzez osobowość Mussoliniego, człowieka, bohatera, uprzywilejowanego i opatrznościowego ducha, w którym ucieleśnia się myślenie i nieustannie wibruje w potężnym rytmie młodzieńczego życia, będącego w pełni rozkwitu ${ }^{20}$.

Kwestia postawy Gentilego wobec faszyzmu była spójna z jednym z fundamentalnych elementów jego myśli politycznej, czyli z koncepcją religijną i totalitarną polityki i państwa. Była to realna aktualizacja pewnej woli uniwersalnej, historycznie określonej, wobec której jednostka, jako przejaw egoistyczny, musi zniknąć i poświęcić siebie samą - w sensie religijnym - idei, która ją przewyższa. Przez to poświęcenie i przez indywidualną abnegację idea ta realizowała się ${ }^{21}$. Jest to znaczące, ze względu na to, iż za prymarne zadanie faszyzmu Gentile uważał integralną restytucję suwerenności

14 G. Gentile, Początki ideologii faszystowskiej (1918-1922), Warszawa 2011, s. 14.

15 Tamże, s. 14.

16 A. Haywood, Ideologie polityczne, Warszawa 2007, s. 234.

17 J. W. Borejsza, Faszyzmy europejskie (1922-1945), Warszawa 1979, s. 342.

18 G. Gentile, dz. cyt., s. 337.

19 A. Haywood, dz. cyt., s. 234.

20 Tamże, s. 337-338.

21 Tamże, s. 359. 
państwa poprzez wychowanie jednostki w poczuciu, że jest ona szczególną częścią społeczeństwa. Podkreślał społeczny i historyczny charakter jednostki, a zatem niemożność pojmowania życia na modłę atomistyczna, łączył faszyzm z marksizmem, starając się przedstawić pierwszy jako przezwyciężenie drugiego, a nie jako antytezę ${ }^{22}$. Ideał nowego Włocha był - zdaniem Gentile - realizowany przez młodzież faszystowska, młodzież idealistyczną Italii, którą „,stworzono i która musiała być jeszcze stwarzana"23.

Interpretując życie w sposób, idealistyczny Gentile pragnął uwolnić wychowanie od wszelkiego materialistycznego nalotu, od różnych przesądów realistycznej pedagogiki. Do takich przesądów zaliczał monadologię, w której fakt wychowania polega na duchowym oddziaływaniu nauczyciela na ucznia. Nie zgadzając się z tym, Gentile twierdzit, że wychowanie nie jest dwoistościa, ale jednością twórczego aktu myślowego, w którym zespalają się ze sobą uczeń i nauczyciel, gdy zajmują się przedmiotem swojej lekcji. Zniesienie dwoistości Gentile uważał za istotny warunek wszelkiego wychowania i nauczania. Przesąd chronologizmu związany był z przygotowaniem dziecka jako istoty niedojrzałej do życia dorosłych. Zdaniem Gentilego, ograniczać wychowanie do lat młodocianych, znaczy odmawiać pozostałemu okresowi życia duchowości. „Duch według niego rozwija się nieustannie, jest procesem wiecznym, który nie ma początku, ponieważ nie duch istnieje w czasie, ale czas w duchu. Ostatni przesąd związany jest z pedagogizmem"24. Według pedagogizmu wiedza nie jest pracą ducha, lecz gotowym wytworem, rzeczą istniejąca już przed uczeniem sięucznia i to rzecza, która pozostaje zawsze w jego posiadaniu. Gentile sądził, że uczeń nie może sobie przyswoić wiedzy nie zindywidualizowawszy jej, nie uczyniwszy jej ośrodkiem swego duchowego rozwoju ${ }^{25}$.

W swoich założeniach dotyczących wychowania Gentile zwracał uwagę na zagadnienie wolności, która miała być jego najważniejszą zasadą i dlatego też autonomia pedagogiki, autonomia dóbr kształcących była konsekwencjąjego filozofii idealistycznej, opartej na twierdzeniu, że duch może być pojęty tylko jako wolny ${ }^{26}$. W pojęciu jedności wychowania godzi się łatwo wychowanie fizyczne i kształcenie charakteru²7. Sądzil, że każda „,zzęść naszego organizmu tworzy niezróżnicowaną całość naszej żywej istoty; w chwili, gdy np. coś piszemy, ruchy naszej ręki nie tylko zależą od naszej woli, ale są naszą wolaj jest to bowiem jeden i ten sam proces, za pomocą którego urzeczywistniamy samych siebie"28.

Zamiarem Mussoliniego było z kolei, (kosztem indywidualizmu, optymizmu) kultywować odwagę, skromność, wyrozumiałość, jako postawy godne naśladowania, przy jednoczesnym odrzuceniu, jak twierdził duce, amerykańskiego cynizmu oraz materializmu ${ }^{29}$. Sam duce delektował się młodością faszyzmu, jako ruchu społeczno-politycznego, jedynego w swoim rodzaju, ale głównie nowoczesnego. I chociaż faszyzm nie był towarem eksportowym, znajdował uznanie i naśladowców w Europie i na świecie. Ten młody ustrój realizowany w młodych Włoszech był budowany przy udziale młodych ludzi, którzy mieli być przyszłością narodu - godną tego miana: pracowita, wierząca, ofiarna, słuchająca starszych i przełożonych ${ }^{30}$.

Kult młodości był również istotnym elementem w konstruowaniu koncepcji „nowego człowieka”. Sprzęgnięty był przekonaniem, że młode pokolenie jest nadzieją nadchodzącej wielkości faszyzmu, państwa oraz narodu. W regulaminie technicznym zawarto cele organizacji Balilla. Związane one były z realizacją edukacji fizycznej, moralnej i paramilitarnej wespół z wychowaniem kulturalnym, przysposobieniem zawodowym oraz opieką religijną. Były to cele realizowane także przez inne podmioty publiczne, np. szkoły, czy Kościół. „Minister edukacji narodowej Balbino Giuliano ze zrozumiałych powodów eksponował zbieżność funkcji wychowawczo-edukacyjnych wszystkich, których celem jest zbudowanie nowej cywilizacji włoskiej łączącej nowocześnie ukształtowanego ducha ze sprawnym ciałem" ${ }^{\prime \prime 31}$.

Twierdzono, że „pojawienie się młodych Włoch może ożywić dekadencką Europę, a to właśnie dzięki włoskiej witalności. W tych ideologicznych ramach młodość osiagnę̧ła status narodowego prawa. Różnice pomiędzy młodymi a starymi przedstawiane były poprzez ich wigor, kreatywność oraz jurność. Taki obraz świata był w całości integralną częścią Eu-

22 Tamże, s. 369.

23 Tamże, s. 367.

24 L. Chmaj, Prady i kierunki w pedagogice XX wieku, Warszawa 1962, s. 428.

25 L. Chmaj, Prady i kierunki w pedagogice XX wieku, Warszawa 1962, s. 427-428.

26 Tamże, s. 429.

27 Tamże, s. 430.

28 Tamże

29 D. M. Smith, Mussolini, Warszawa 1994 s. 199.

30 S. Sierpowski, Totalitaryzm we Wtoskim wydaniu, https://repozytorium.amu.edu.pl/jspui/bitstream/10593/709/1/Totalitaryzm\%20we $\% 20$ w\%C5\%820skim\%20wydaniu.pdf, 23.12.2014.

31 S. Sierpowski, dz. cyt. 
ropejskiego faszyzmu, a w szczególności włoskiego faszyzmu“"32. Nieustannie „koncepcja młodości przeciwstawiana była dekadenckiej starości świata, tak samo jak przeciwko sztuczności i cyniczności”33. Podkreślano, że młodzi muszą „"zuć ducha żołnierza" oraz, że mogą działać lepiej niż starzy, ponieważ nie są zepsuci przez niefaszystowskie doświadczenie. Będąc kimś więcej niż kolejnym pokoleniem faszystów, mieli być moralną siła, która zagwarantuje trwałość i świetność faszyzmu ${ }^{34}$.

Fascynacja stworzenia przez Mussoliniego nowego, lepszego Włocha związana była z duchowym charakterem i poczuciem rasowym ${ }^{35}$. Problem ten podnosił także wcześniej, zanim znalazł się na szczycie władzy w państwie. W swoim przemówienie zaznaczał, że „dla faszyzmu kwestia rasowa ma wielkie znaczenia. Faszyści muszą troszczyć się o kondycję rasy, ponieważ rasa jest materiałem, z którego także chce się tworzyć historię ${ }^{\prime \prime 36}$.

Kwestie rasowe były szczególnym zagadnieniem w faszystowskich Włoszech. Warto zauważyć, że im Mussolini był bliżej Hitlera i zawarcia sojuszu z nim, jego poglądy na rasę stały się bardziej radykalne. Toczył się szereg sporów związanych z kwestiami eugenicznymi, zresztą podobnie, jak w Stanach Zjednoczonych czy Niemczech. Z początku niektóre radykalne koncepcje eugeniczne były cenzurowane i nierealizowane. Jednak można zwrócić uwagę na koncepcje związane zarówno z kultem młodości, rasa, zdrowiem oraz rozwojem jednostki. Zdaniem Edmonda Vercellesiego, dzięki sportowi i gimnastyce można by było wyeliminować „szereg deformacji fizycznych", co pomogło by powrócić do normalności „nazbyt szczupłym i mniej rozwiniętym organizmom”. Z kolei w opinii pediatry i higienisty Marcella Belletiego sporty kobiece, w szczególności gimnastyka, bez nadmiernego wysiłku, rzucania dyskiem, oszczepem, sprintu, szermierki, pływania, tenisa, jazdy na nartach i kajakarstwa, pozwoliłaby przygotować kobiety do macierzyństwa, tym samym stając się czynnikiem zdrowia fizycznego i budującym morale rasy37. Giuseppe Lucidi twierdził, że płody rolne mają wpływ na jednostkę, zarówno pod względem fizycznym, jak i duchowym. Podobne poglądy głosił Vercelessi, którego zdaniem bezsprzeczne jest , że „zdrowi i silni synowie to bezpośredni efekt odżywania, tak jak silna i zdrowa rasa jest dzieckiem dobrze odżywionej populacji' ${ }^{38}$.

Bezpośrednie wskazówki oraz wyznaczane cele były próbą zdefiniowana nowego idealnego człowieka faszystowskiego. Ważne jest jednak również, w jaki sposób i jakiej formie faszyści starali się swoje plany wprowadzić.

\section{ORgANIZACJE I SZKOŁA}

Faszyści powoływali do życia wiele organizacjiji ${ }^{39}$, które miały stowarzyszać młodzież. Najbardziej znaną była Balilla. Zrzeszała ona chłopców od 8-14 roku życia. Odpowiednikiem męskich zrzeszeń było przeznaczone dla dziewcząt Piccole Italiane. „Grupy zrzeszające najmłodszych przypomniały harcerstwo lub skauting z innych krajów, choć wyraźny był ich aspekt militarny. Już zajęcia ze stosunkowo małymi dziećmi obejmowały musztrę i noszenie karabinów-zabawek. We wszystkich częściach kraju do takich organizacji chętniej przystępowali chłopcy, ponieważ, jak sądzono szanująca się kobieta nie powinna paradować w mundurze. Organizacje te były elementem wychowania w duchu konformizmu i militaryzmu" ${ }^{\prime \prime 0}$.

Istotnym komponentem były również cele wyznaczane przez faszystów, wprowadzane do ideologii wychowania nowego człowieka w szkołach. Jak zaznacza L. Minio-Paluello „,w pierwszych siedmiu deklaracjach statutu szkół ujęto zasady oraz metody edukacji szkół faszystowskich" ${ }^{\prime \prime 1}$. Obejmowały one: moralną, politycznąi gospodarcząjedność włoskiego narodu, który miał mieć świadomość integralności z państwem faszystowskim; „okresy edukacji szkolnej i politycznej pokrywające się z faszystowskim porządkiem, w której szkoły G.I.L i G.U.F² razem stanowić miały jeden z instrumentów edukacji faszystowskich; studia organizowane zgodnie z rzeczywistą zdolnością fizyczną i intelektualną młodzieży

32 G.. L. Moss, The Genesis of Fascism, "Journal of Contemporary History" 1966, s. 19.

33 M. A. Ledeen, Fascism and Youth, ,Journal of Contemporary History” 1969, vol. 4, no. 3, 137.

34 Tamże, s. 139-140.

35 Tamże.

36 S. Sierpowski, Rasizm faszystowskich Wtoch, https://repozytorium.amu.edu.pl/jspui/bitstream/10593/708/1/Rasizm\%20faszystowskich\%20Wloch.pdf, 23.12.2014).

37 F. Cassata, Eugenika i rasizm biologiczny w propagandzie faszystowskiej „La Difesa Della razza (1938-1942), [w:] M. Gawin, K. Uzarczyk, (red.), Eugenika, biopolityka, państwo, Warszawa 2010, s. 88.

38 E. Vervelesii, Alimentazione degli italiani," La Difesa Della Razza" 1939, nr 17, s. 41.

39 Szczegółowo rozwój organizacji opisuje L. Minio-Paluello, Education in Fascist Italy, London-New York-Toronto 1946.

40 R. Eatwell, Historia Faszyzmu, Poznań 1999, s. 131.

41 L. Minio-Paluello, dz. cyt., s. 205.

42 Grappi Universitari Fascist, Gioventu Italiana del Littorio. 
mające na celu kształtowanie moralne i kulturowe oraz przygotowanie wojskowe i polityczne zgodne z G.I.L; edukację fizyczną realizowaną przez organizację G.I.L; pracę, która miała być chroniona przez państwo we wszystkich jej formach, czy to intelektualnych, manualnych lub technicznych; naukę, ćwiczenia fizyczne i prace ręczne stanowiące w szkole odpowiednie środki do sprawdzenia umiejętności; oraz zagadnienia związane z istnieniem naturalnej solidarności pomiędzy rodziną a szkoła, ściśle i nieprzerwanie współpracująca, aż do zakończenia szkoły oraz przystosowania młodych. Rodzice i krewni mieli uczestniczyć w życiu szkoły i uczyć się tam wspólnych dla nich celów i metod, które pomagają wzmocnić dzieci i młodych ludzi na ścieżce do tradycyjnej religii i przeznaczenia Włoch" ${ }^{\prime \prime 3}$.

W doktrynie faszystowskiej w obszarze edukacji akcentowano jeszcze jeden ważny element, mianowicie sport. W przytoczonych zasadach szkół faszystowskich akcentowano w wielu punktach wychowanie fizyczne. Jak zauważa S. Sierpowski „faszyzm wdzierał się do życia dzieci i młodzieży wręcz frenetycznym kultem sportu, walki, zwycięstwa nad słabszym, mniej sprawnym, mniej odważnym. Doroczne igrzyska młodzieżowe nastawione na powszechna rywalizację dzieci i młodzieży z klasyfikacjami uwzględniającymi grupy wiekowe, zaangażowanie prowincji, miast, wsi, szkół itp. angażowały nie tylko całą młodzież, ale ich opiekunów, trenerów, rodziców, krewnych" ${ }^{\prime 4}$. Należy zauważać dużą zgodność w realizacji zasad szkół faszystowskich, gdzie rodzina i krewni włączani byli do życia młodzieży włoskiej. Co więcej, sport stawał się coraz ważniejszym elementem propagandy faszystowskiej. Odciągał uwagę od innych spraw, zwłaszcza możliwości decydowania o sprawach politycznych. Można go było także wykorzystać, by wzmacniać poczucie dumy i przynależności narodowej. Uczyniono tak z piłką nożna, która stała się dla Włochów bardzo istotna po tym, jak drużyna narodowa wygrała rozgrywane we Włoszech Mistrzostwa Świata w 1934. Rząd, który sponsorował zawody sportowe, podkreślał w ten sposób wartości najważniejsze dla „,nowego człowieka” , którego chciał stworzyć faszyzm"

\section{DOKTRYNA FASZYZMU}

Poza bogatą literaturą przedmiotu ${ }^{46}$, umożliwiającą przedstawienie ideału człowieka istotna, (a zarazem wiążąca wszystkie dążenia faszystów) jest Doktryna faszyzmu. Jest to „niewielka broszurka, która jest pierwszorzędnym i szczególnym dokumentem historycznym. Autor - Benito Mussolini (1883-1945) - twórca i niekwestionowany wódz (wł. duce) faszyzmu musi być uznany za najbardziej kompetentnego świadka historii swego ruchu. Jest to więc świadectwo bezpośrednie, dokument z "pierwszej ręki". O szczególnym znaczeniu Doktryny faszyzmu przesądza także moment i cel spisania tego tekstu. Mussolini napisa ${ }^{47}$ tę niewielką rozprawkę w 1932 r. na prośbę wydawców Enciclopedia Italiana Trecccaniego. Pisał ją więc w dziesięć lat po zdobyciu władzy, pisał u szczytu powodzenia politycznego, pisał w chwili, gdy ostatecznie właśnie uformował system dyktatury we Włoszech i pisał dla szerokiego kręgu czytelników. W tych okolicznościach dokument nabiera cech migawkowej fotografii faszyzmu - w chwili jego szczytowych osiagnnięć i w porze uznanej przezjego twórcę za najwłaściwsząa" ${ }^{\prime \prime}$. Powyższe treści te wzbogacają wiedzę o dążeniach faszystów związanych ze stworzeniem nowego Włocha. Są również istotnym elementem, który finalizuje koncepcję ideału wychowania faszystowskiego. Wskazują, co jest szczególnie znaczące, na obszary, w których owa jednostka ma osiagnąć doskonałość. Mowa tutaj o wspomnianym idealizmie G. Gentilego, czucia żotnierskiego ducha, znaczeniu wychowania fizycznego i duchowego, godności, moralności oraz honoru.

W odniesieniu do treści, które przedstawił Mussolini, i zaprezentowanego tematu istotne są te bezpośrednio odnoszące się do jednostki, jej postaw, dążeń, zachowania, świadomości. W momencie analizowania ideału wychowania jednostki w faszystowskich Włoszech nie należy zapominać o ujmowaniu jej w kontekście państwa, ponieważ jak twierdził

43 L. Minio-Paluello, dz. cyt., s. 205-206.

44 S. Sierpowski, dz. cyt., s. 20.

45 R. Eatwell, dz. cyt., s. 129.

46 S. Sierpowski, Faszyzm we Wtoszech 1919-1926, Wrocław-Warszawa-Kraków-Gdańsk 1973. P. Foro, Wlochy Faszystowskie, Kraków 2008. R. Eatwell, Historia faszyzmu, Poznań 1999. R. Paxton, Anatomia Faszyzmu, Poznań 2005. J. A. Gierowski, Historia Włoch, Wrocław 1985. T. Filipak Polityczna i społeczna doktryna faszyzmu, Warszawa 1985. J. Borejsza, Szkoty nienawiści: historia faszyzmów europejskich 1919-1945, Wrocław 2000. P. Morgan, Italian Fascism, 1915-1945, 2004. B. Spackman, Fascist Virilities, Rhetoric, Ideology, and Social Fantasy in Italy, London 1996. K. Passmore, Fascism, A very short introduction, New York 2002. M. Durhan, Woman and Fascism, London-New York, 1998. S. G. Payne, A history of Fascism, London 1995. W. Laqueur, Fascism. Past, Present, Future, New York 1996. R. De Felice, Interpretacje faszyzmu, Warszawa 1976. M. Leeden, Renzo De Felice and the Controversy over Italian Fascism, "Journal of Contemporary History" 1976, no 11. F. L. Carsten, The Rise of Fascism, Londyn 1967. E. Gentile, Poczatki ideologii faszystowskiej (1918-1922), Warszawa 2011. L. La Rovere, Fascist Groups in Italian Universities: An Organization at the Service of the Totalitarian State, "Journal of Contemporary History" 1999, vol. 34, no. 3 .

47 Najprawdopodobniej twórca jest E. Gentilie

48 B. Mussolini, Doktryna Faszyzmu, Poznań-Łódź 1992, s. 7-8. 
Mussolini „w państwie faszystowskim jednostka jest nie unicestwiona, lecz raczej pomnożona, tak jak w pułku żołnierz jest nie pomniejszony, lecz raczej pomnożony przez liczbę swoich towarzyszy. Państwo faszystowskie organizuje naród, lecz zostawia następnie jednostkom wystarczające pole ruchów: ograniczyło wolności nieużyteczne lub szkodliwe, a zachowało te, które są istotne. Rozstrzygać w tej dziedzinie nie może jednostka, lecz państwo" ${ }^{49}$. Toteż „,człowiek faszyzmu jest jednostka, która jest narodem i ojczyzna, prawem moralnym, które skupia jednostki i pokolenia więzią tradycji i misji, która niweczy instynkt życia zamkniętego w ciasnym kole rozkoszy, aby stworzyć nakazem obowiązku życie wyższe, wyzwolone z granic czasu i przestrzeni: życie, $\mathrm{w}$ którym poprzez samozaparcie, poprzez poświęcenie swoich osobistych korzyści, poprzez samą śmierć urzeczywistnia to istnienie na wskroś duchowe, w którym tkwi jego wartość jako człowie$\mathrm{ka}^{\prime \prime 50}$. Podsumowaniem takiego podejścia są słowa Mussoliniego, który napisał ,jednostki i grupy dają się pomyśleć o tyle, o ile istnieją w państwie" ${ }^{\prime \prime 2}$. Określenie relacji jednostka-państwo pozawala ukazać obraz człowieka-faszysty, nowego włoskiego człowieka. Przede wszystkim dla „faszysty - jak pisał Mussolini - wszystko mieści się w państwie i poza państwem nie istnieje nic ludzkiego ani duchowego, ani tym bardziej nie posiada jakiejkolwiek wartości" ${ }^{\prime 52}$. „Życie w pojęciu faszysty - jak pisał Mussolini - jest poważne, surowe, religijne: całe wzniesione $\mathrm{w}$ świecie podtrzymanym moralnymi i odpowiedzialnymi siłami ducha. Faszysta gardzi życiem wygodnym ${ }^{\prime \prime 53}$. "Kocha on naprawdę swego bliźniego, lecz ten bliźni nie jest dla niego pojęciem mętnym i nieuchwytnym: miłość bliźniego nie przeszkadza koniecznej surowości wychowawczej, a tym mniej zróżnicowaniu i uznawaniu dystansów" ${ }^{\prime \prime 5}$. W konsekwencji Mussolini, określając swoje dążenia, pisał, że „faszyzm chce odnowić nie formy życia ludzkiego, lecz treść, człowieka, charakter, wiarę. I w tym celu pragnie karności i autorytetu, który by zstąpiły w dusze, i zdobył w nich rząd niezaprzeczony. Przeto jest jego symbolem pęk rózg liktorskich, symbol jedności, siły i sprawiedliwości" ${ }^{\prime 25}$. Dodatkowo „wierzono zawsze w świętość i w bohaterstwo, to jest w czyny, w których nie działa żaden motyw ekonomiczny, bliski czy daleki”'56. Następstwem takiej postawy miało być stworzenie żołnierzy, którzy wiedza, za co się bija, bo tacy są zawsze najlepsi. Faszyzm, jak twierdzono, może i powinien wybrać sobie jako hasło dwumian Giuseppe Mazziniego: Myśl i Czynn ${ }^{57}$. Ponadto tradycja rzymska miała być ideą siły ${ }^{58}$.

\title{
ZAKOŃCZENIE
}

Nuovo Italiano miał mieć takie cechy jak: żądzę czynu, odwagę, poświęcenie w interesie faszyzmu, narodu - wielkiego na miarę idealizowanych czasów antycznych ${ }^{59}$. Giovanni Gentile pragnął jednak, aby wszelkie wychowanie już od samego początku było wychowaniem filozoficznym, kształtowaniem konkretnego myślenia ludzkiego. Jego zadaniem miało być wychowanie prawdziwych ludzi, a nie fragmentów człowieczeństwa bezbronnych wobec rzeczy. Uduchowienie rzeczy i ożywienia ducha - w tym idealista widział istotę wychowania humanistycznego $w$ filozoficznym znaczeniu tego słowa ${ }^{60}$.

Rozważania nad ideałem wychowania faszystowskiego opierają się głównie na idealizmie G. Gentilego. Wytyczył on konkretną drogę, którą miała przebyć jednostka, ciągle doskonaląc swojego ducha. Istotne jest to, iż tworzenie nowego człowieka w czasach faszyzmu we Włoszech przebiegało według szczegółowo zaplanowanego schematu. Działania te (zarówno Mussoliniego, jak i Gentiliego) doskonale obrazowały dążenia faszystów, jak i sytuację społeczno-polityczną Włoch. Ideał wychowania z wyznaczonymi - przez organizacje młodzieżowe i akademickie, szkoły - celami realizowały swoje założenia.

Wspominana przeze mnie anatomia ideału wychowania opisuje jednostkę wraz ze wszystkimi mechanizmami koniecznymi do jej funkcjonowania w ideale faszyzmu. Mussolini, propagując kult młodości, doskonale wiedział, jakiej jednostki potrzebowały Włochy: człowieka honoru, oddania, doskonałego, posłusznego żołnierza. Z drugiej strony miał być to człowiek świadomy swojej przynależności, religijny ciągle rozwijający swojego ducha.

\author{
49 Tamże, s. 44-45. \\ 50 Tamże, s. 16. \\ 51 Tamże, s. 40. \\ 52 Tamże, s. 20. \\ 53 Tamże, s. 17. \\ 54 Tamże, s. 31. \\ 55 Tamże, s. 24. \\ 56 Tamże, s. 32. \\ 57 Tamże, s. 51. \\ 58 Tamże, s. 54. \\ 59 S. Sierpowski, dz. cyt. \\ 60 L. Chmaj, Prądy i kierunki w pedagogice XX wieku, Warszawa 1962, s. 431.
}


Koncepcja „nowego człowieka” nie była jednak przestrzegana przez włoskie środowiska, co było powszechne dla europejskich faszyzmów ${ }^{61}$. Zresztą „„dążenie do doskonałości wydaje się znakomitym przepisem na rozlew krwi i bez znaczenia jest nawet fakt, że żądają jej najszczersi idealiści, ludzie najczystszego serca. Nikt inny jak Immanuel Kant, najsurowszy moralista, jaki się kiedykolwiek urodzil, powiedział w przebłysku iluminacii, że z pokrzywionego drzewa człowieczeństwa nie da się wyciosać nic prostego. Wciskanie ludzi na siłę w zgrabnie skrojone uniformy, wedle wymagań schematów branych za dogmat, prawie zawsze jest drogą wiodącą do odczłowieczenia"62. Podobnie sądzi Jerzy Trębicki, twierdząc, że „ideał wychowania jest nieosiągalną doskonałością w czystej postaci” ${ }^{\prime \prime}$. Trudność ta nie była przeszkoda, aby koncepcja idealnej jednostki faszystowskiej była wykorzystywana przez innych teoretyków wychowania, ideologów, polityków okresu pierwszej połowy XX w.

\section{Bibliografia:}

[1] Araszkiewicz F., Ideały wychowawcze Drugiej Rzeczypospolitej, Warszawa 1978.

[2] Araszkiewicz F., Warunki prawomocności ideału wychowawwczego, "Człowiek i Światopogląd” 1984, nr 9.

[3] Berlin I., Pokrzywione drzewo człowieczeństwa, Warszawa 2004.

[4] Borejsza J. W., Faszyzmy europejskie (1922-1945), Warszawa 1979.

[5] Borejsza J. W., Mussolini byt pierwszy, Warszawa 1989.

[6] Borucki M., Mussolini, Warszawa 1975.

[7] Cassata R., Eugenika i rasizm biologiczny w propagandzie faszystowskiej „La Difesa Della Razza (1938-1942), [w:] Gawin M., Uzarczyk K. (red.), Eugenika, biopolityka, państwo, Warszawa 2010.

[8] Chmaj L., Prady i kierunki w pedagogice XX wieku, Warszawa 1962.

[9] Eatwell R., Historia Faszyzmu, Poznań 1999.

[10] Gentile G., Początki ideologii faszystowskiej (1918-1922), Warszawa 2011.

[11] Haywood, A., Ideologie polityczne, Warszawa 2007.

[12] Kunowski S., Podstawy wospótczesnej pedagogiki, Warszawa 1981.

[13] Ledeen M. A., Fascism and Youth, "Journal of Contemporary History", 1969, vol 4, no. 3.

[14] Minio-Paluello L., Education in Fascist Italy, London-New York-Toronto 1946.

[15] Moss G. L., The Genesis of Fascism, "Journal of Contemporary History" 1966.

[16] Mussolini B., Doktryna Faszyzmu, Poznań- Łódź 1992.

[17] Nowak M., Teorie i koncepcje wychowania, Warszawa 2008.

[18] Smith D. M., Mussolini, Warszawa 1994.

[19] Trębicki J., W stronę Arkadii czy Apokalipsy, Warszawa 1978.

[20] Zarzecki L., Teoretyczne podstawy wychowania. Teoria i praktyka w zarysie, Jelenia Góra 2012.

\section{Netografa:}

[21] Sierpowski S., Rasizm faszystowskich Włoch, https://repozytorium.amu.edu.pl/jspui/bitstream/10593/708/1/Rasizm\%20faszystowskich\%20 Wloch.pdf, 23.12.2014.

[22] Sierpowski S., Totalitaryzm we Wtoskim wydaniu, https://repozytorium.amu.edu.pl/jspui/bitstream/10593/709/1/Totalitaryzm\%20we\%20 w\%C5\%82oskim\%20wydaniu.pdf, 23.12.2014.

61 M. A. Ledeen., Fascism and Youth, „Journal of Contemporary History”, 1969, vol. 4, no. 3, s. 152-153.

62 I. Berlin, Pokrzywione drzewo czlowieczeństwa, Warszawa 2004.

63 J. Trębicki, W stronę Arkadii czy Apokalipsy, Warszawa 1978, s. 30. 